\title{
Predicting the Growth of e-Commerce using Trendline Analysis: A Case Study of Ogun State, Nigeria
}

\author{
Ebenezer N. Igwe ${ }^{1}$ and Olumuyiwa B. Alaba ${ }^{2}$ \\ Department of Computer Science \\ Tai Solarin University of Education, \\ Ijagun, Ogun State, Nigeria \\ ${ }^{1}$ Email: igweebenezerndubuisi [AT] gmail.com \\ ${ }^{1}$ Email: olumuyiwaalaba [AT] gmail.com
}

Abstract--- There is a growing interest from e-commerce planners and other planning agencies in the Information Technology world to measure and forecast the growth of ecommerce in developing countries like Nigeria. The difficulties lie in finding the best forecasting model that can incorporate both the internal and external barriers that influence the full adoption and diffusion of e-commerce. The study attempts to identify the relevant e-commerce tools and its spread in Ogun East Senatorial District as well as formulating a mathematical model for e-commerce adoption and diffusion. A well-structured questionnaire was used to collect data from 126 respondents and analyzed using Trendline, a built-in analysis tool in Microsof ${ }^{\circledR}$ Office Excel version 2013. The study identified PCs/laptops, ATM cards, e-mail services, mobile money transfer, e-commerce Websites, and point-of-sales (POS) terminals as ecommerce tools used by the respondents. The results of the study show that majority of the e-commerce users/adopters were single female students between the ages of 21 and 30 years, with university education owing to a proportion of $63 \%$ of the respondents while the earliest adopted ecommerce tools in descending order were tablets/smartphones, PCs/laptops, ATM cards, and email services. The results further show that the most popularlyused tools were e-commerce websites (98\% responses), email services (94\% responses), mobile money transfer (94\% responses), POS terminals (94\% responses), tablets/smartphones (93\% responses), PCs/laptops $(87 \%$ responses) and ATM cards ( $80 \%$ responses). Based on the findings of this study, it is therefore recommended that government should promote the use and development of ecommerce, notably by reducing the costs of access to technology, through the liberation of trade in software and hardware.

Keywords-- E-Commerce, adoption, diffusion, infusion, barriers, trendline.

\author{
Olalere A. Abass \\ Department of Computer Science \\ Tai Solarin College of Education, \\ Omu-Ijebu, Ogun State, Nigeria \\ Email: olaabas [AT] gmail.com
}

\section{INTRODUCTION}

The rapid expansion of the Internet and network technology links countries throughout the world and businesses are no longer confined to their immediate regions, cities, or states. The developments in telecommunications in Nigeria since August 2001, the global diffusion of the Internet, and the emergence of e-commerce have helped in the creation of business environments that fosters the globalization of markets throughout the world and the World Wide Web has made our lives a lot more convenient. Nigeria like other countries across the globe uses the Internet to communicate verbally and visually with our friends and family in far-off regions, book flights, watch movies and complete long-distance online education programmes. Thus, there are many other aspects of our daily lives where we would use the Internet like in the area of e-commerce.

The Internet revolution has led to the emergence of ecommerce in business transactions [1]. According to [2], ecommerce is the process of buying and selling products and services using computer networks, such as the Internet. Ecommerce cuts across all forms of businesses, which include Business-2-Business, Business-2-Customer, and Customer-2Customer [3]. E-commerce adoption is defined as the degree to which an innovation is perceived in organizational activities [4]. Therefore, investigating the barriers of e-commerce adoption and diffusion would help business organizations with the effective use and spread of e-commerce technology [5].

A new dimension to Internet accessibility in Nigeria has been introduced with hundreds of thousands of people now accessing the Internet on their WAP (Wireless Application Protocol) - enabled mobile phones, smartphones, and their PCs. This is largely due to the introduction of GPRS (General Packet Radio Service), EDGE (Enhanced Data Rates for GSM Evolution), 3G ( $3^{\text {rd }}$ Generation), and $4 \mathrm{G}$ ( $4^{\text {th }}$ Generation) network connectivity by the operators. The banking sector, telecommunication providers, other financial institutions, public and private businesses in Nigeria are also beginning to adopt the e-commerce paradigm.

The relative growth in the use of the Internet and other ICT tools has enabled e-commerce technology to grow 
exponentially in Nigeria, which in turn, increases business efficiency, but despite the benefits derived from the use of the Internet, the high cost of installing the infrastructures and its management hinders businesses most especially SMEs to adopt and operate electronic commerce [6]. No doubt that many barriers hinder the adoption and diffusion of e-commerce innovation in Nigeria but for the sake of clarity, the following barriers are mentioned in this paper: enabling infrastructure factors (technology, network, availability of ICT skills, qualified personnel); cost factors (costs of ICT equipment, network infrastructures, cost of a computer and other telecommunication devices); security and trust factors (uncertainty of payment methods, the risk of third party intrusion and legal frameworks on e-commerce), poor distribution logistics, lack of feel-and-touch associated with online purchases, problems in returning products, and illiteracy. The majority of business operators although have heard about the use of e-commerce, unfortunately, only a few have used it in their business transactions.

The motivation of this paper hinges on the fact that the extent of e-commerce adoption and diffusion in Ogun East Senatorial District is still unclear, hence very scanty. More so, papers written on e-commerce in developing countries are often lacking predictive models and are purely conceptual. Consequently, there is always a problem or difficulty in measuring the growth of the diffusion of innovation. Based on so many technological innovations in vogue today, measurement of diffusion can be obvious. For instance, measuring the adoption and diffusion of cell phones is simply a matter of tracking sales of cell phones or subscriptions [7]. But tracking the growth of e-commerce is much more difficult, hence, the need for this paper. Therefore, this paper will serve as a blueprint for e-commerce users to evaluate the level of ecommerce adoption and diffusion in Ogun East Senatorial District of Ogun State, Nigeria. Also, the objectives of this paper would be to identify the relevant e-commerce tools used in Ogun East Senatorial District, identify the spread and impact of e-commerce in Ogun East Senatorial District and thus formulate a mathematical model for e-commerce adoption and diffusion in Ogun East Senatorial District.

\section{RELATED WORKS}

[8] explains that e-commerce has not been as successfully adopted in developing countries. According to [9], e-commerce in Nigeria is gradually increasing in line with its growth. Therefore, the intensity of the use of e-commerce in the country is expected to be maintained due to its accelerated increase [10]. To explore the relevance of e-commerce and the opportunity for its growth in developing countries like Nigeria, it is important to understand some national factors that affect its adoption and diffusion. Developing countries face insurmountable barriers getting on the electronic highway. These factors are classified as either internal or external factors or barriers. External and internal factors in developing countries like Nigeria are low when compared to the developed countries which may be responsible for the slow rate of e-commerce growth in developing countries.

Internal barriers are those barriers that exist within an organization and they can also be resolved within such an organization, that is, they are within the control of an organization. They typically include awareness and ecommerce knowledge by owners, lack of capacity and resources, return on investment, lack of general awareness, uncertainty about the benefits of electronic commerce, low use of the Internet by customers and suppliers, lack of adequate Internet security, and trust-building principles. The external barriers are those barriers that lie outside the immediate control of an organization. These include lack of infrastructural facilities, lack of funds, lack of governmental investments, political condition, economic condition, and external influence (e.g. international donors).

The epileptic power supply in Nigeria particularly in Ogun East Senatorial District is one of the major factors affecting the full adoption and diffusion of e-commerce. It is imperative to know, therefore, that e-commerce technology work hand-inhand with stable sources of electricity supply. This means that if the power issue bedeviling the economic growth in Nigeria is resolved, e-commerce will realize sustainability, whereby companies will not only realize the economic gain but will also have contributed to environmental and social aspects [11]. It cannot be argued that electricity is the most discouraging factor of e-commerce adoption in the study area as a whole. Some individuals in the Senatorial District have taken it upon themselves to acquire and set up the necessary infrastructures needed to run the organization and to better serve their customers [12]. For example, Mike Adenuga, the Chairman of Globacom, introduced a 9,800 km long submarine cable network across the United Kingdom, Spain, Portugal, and 14 African countries to establish a dedicated link to the United States. This is the first superb initiative of its kind to be executed by an individual in Nigeria.

The fund is another powerhouse to the adoption and diffusion of e-commerce technology in Ogun East Senatorial District. Most Nigerians cannot expand their IT resources due to limited access to capital [13]. This is one of the major common factors affecting the growth of e-commerce in Ogun East Senatorial District and in Nigeria as a whole. Most entrepreneurs or e-commerce users in Nigeria do not have access to bank soft loans or funding to support the development of e-commerce technology in their businesses due to a lack of adequate collateral [14]. Also paying back loans that have highinterest rates and high bank charges can be too much of a burden for the majority of Nigerians to bear.

[2] opined that e-commerce enables the comprehensive digital execution of business processes between suppliers and customers via global public and private networks. Government initiatives are very important in the adoption and diffusion of ecommerce and other ICT tools in general. They can be in terms of promotion of ICT usage, education, and the establishment of an adequate regulatory framework for e-commerce activity including taxation and tariff for revenue generated through e- 
commerce and intellectual property protections. Government initiatives are affected by many other factors which include: the country's political condition, economic condition, geographical condition, socio-cultural condition, and external influence from other countries.

It has also been suggested that one of the most surprising barriers to e-commerce adoption and diffusion in Nigeria is the lack of knowledge of e-commerce technology solutions of how they work, how they should be implemented, and how they can benefit the business sector [15] [12]. Studies have shown that most managers of firms, some of the employees, and consumers could not select an e-commerce technology solution that would be appropriate for a given type of organizational problem [16] [17]. Hence, there is a need for both the managers, employees, and consumers (customers) to undergo some form of training to be aware of the vast changing nature of e-commerce technology and to find the most suitable solution for their business need [13]. It cannot be claimed that Nigeria completely lacks the necessary infrastructures, but it can be argued that the infrastructures are in a poor condition. Similarly, a study conducted by [18] on SMEs in Nigeria found out that for full adoption of e-commerce technology by SMEs in Nigeria, a lot is to be done in the areas of telecom infrastructure, conducive legal environment, deeper infusion of computers, adequate research and development and proper national policy on ecommerce innovation. In a study conducted in Turkey by [19] to find the benefits and the barriers of e-commerce adoption. The study results reveal that the benefits of adoption of ecommerce technology include access to new markets, enhance competitiveness and cost advantage.

Despite the national factors affecting the adoption of ecommerce in Ogun East Senatorial District in Nigeria, it cannot be argued that e-commerce is not growing in the District. The point here is that the technology is yet to make its root in the Senatorial District. In line with its market acceptance and benefit, e-commerce practitioners and researchers are already on their toe towards exploring deeply the technology [20]. Therefore, the replacement of traditional face-to-face commerce to a more dependable electronic commerce is a gradual process and must depend on the following factors such as the level of digitization of the products sold, the process, the delivery methods, collaboration, communication, connection, and computation [21]. This means that if the digital element is found in any one of the factors mentioned, then it can be said that e-commerce exists, but only partial e-commerce. But if all the elements are said to be digital, then it is considered pure ecommerce.

\section{THEORETICAL FRAMEWORK}

\section{a. Technology, Organization and Environment (TOE) Framework}

[22] developed the Technology, Organization and Environment (TOE) framework that has remained very relevant in the spheres of research particularly in the area adoption of innovation. The introduction of TOE framework has provided a useful analytical framework that can be used to carry out a research on the use and assimilation of the various types of information technology innovations. As stated earlier, TOE was developed by Tornatzky and Fleischer in 1990. The framework identifies three aspects of the context that affect the process by which companies and industries adopt and use technology innovation, namely; the technological context, organizational context and the environmental context.

The technology aspect collaborates both the internal and the external factors relevant to the company. Studies have also shown that despite the internal and external factors that impedes the adoption of any technological innovation. One other factor like the return on investment (ROI) is worthy to be mentioned in this paper. Companies are always skeptical about their returns after investing hugely on the adoption of any technological innovation. Take for example, the Rite Foods located in Ososa, a suburb of Ijebu-Ode. All the customers always appear physically in the company premises with their trucks to load their good to different parts of Nigeria. This may take hours, or even days as the company attends to their customers based on first come first served basis. But with the adoption of e-commerce, the physical presence would be eradicated. The organizational context of TOE refers to the size of the organization, organizational readiness and management support. Therefore, it would be wise to say in this paper that organizations that have strong financial backup and technology will are more likely to invest in technological adoption.

The environmental context on the other hand, is associated with the location of the company. That is, the company's area of doing business. How business friendly is the environment in terms of security and infrastructures (power and transportation in the front-line). Researchers have used the TOE framework to study e-commerce adoption and diffusion in many environments and over time of which it would be ideal to be applied in checking the adoption threshold of e-commerce in Ogun East Senatorial District.

\section{a. Roger's Theory on Diffusion of Innovation}

According to [23], e-commerce diffusion is the process by which new technology is accepted by the market or members of a social society. Rogers further opined that the rate of diffusion is the speed with which the new technology spreads from one consumer to another. The theory is divided into two (2) categories: the first category suggests innovation (company), while the second category suggests the adoption of innovation (customer). Based on the definition of the theory, the six (6) factors that affect the rate of adoption of any technological innovation such as e-commerce are relative advantage, compatibility, trialability, observability, complexity, and price.

\section{RESEARCH METHODOLOGY}

The study adopted a survey research method and hence it involved the collection of data from individuals based on their opinions, ideas, and perceptions. The instrument for this study was titled Questionnaire on E-Commerce Adoption and Diffusion Model in Nigeria, tagged "QECADMN. 
The study location for the research was identified as SouthWestern Nigeria following the identification of the sample size of the respondents from which data were collected for data analysis needed for developing a model for e-commerce adoption and diffusion in Nigeria. The study was carried out on e-commerce users located in the South-Western part of Nigeria particularly in the Ogun East Senatorial District of Ogun State. For this study, 200 questionnaires were administered using the simple random sampling method which involved the selection of at least one user at random from each ward located in each Local Government Area (LGA) in Ogun East Senatorial District, Ogun State, Nigeria, for which a total of 126 questionnaires were successfully used in collecting information from the initially intended 200 questionnaires. Ogun East Senatorial District was chosen as the study area because, it is made up of six (6) local government areas and each of these local government areas is highly industrialized. For example, Ijebu-Ode and Sagamu local governments have a lot of industries and the number is still increasing day in day out. But none of these industries are e-commerce oriented.

The e-commerce users used in this study were selected from students of tertiary institutions (between the ages of 18-35 years) particularly the students of Olabisi Onabanjo University, Ago-Iwoye and Tai Solarin University of Education, Ijagun located in Ogun East Senatorial District, market men and women and industrialists (between the ages of 36-50 years) that do their businesses within the six (6) local governments that make up the Senatorial District. The selection process was done through a simple random sampling method whereby each user was selected in each ward in each of the local government areas to represent the true test value of other e-commerce users in the local government.

This study incorporated the use of descriptive statistical techniques to analyze the data collected for this study from the respondents selected. The descriptive statistics methods used helped in the simplification of a large amount of data in a much sensible way by the provision of a summary using both numerical and graphical tools using frequency, tables, graphs, and charts respectively. The adoption and diffusion model for e-commerce was performed using Trendline, the fitting function of the data analysis tool-pack available in the Microsoft $^{\circledR}$ Office version 2013 Excel software add-ins functionality for estimating the trend-line of graphical tables and charts of which a polynomial function of degree, $m$ was used for the study.

In this study, the e-commerce diffusion model was formulated using the cumulative frequency distribution for each subsequent year from the base year (year of adoption) until the desired year (2017). The cumulative frequency of the adopters of e-commerce tools by a given year, $\boldsymbol{X}_{\boldsymbol{y}}$ is the number of adopters of an e-commerce tool from the base year $\boldsymbol{X}_{\boldsymbol{I}}$ till the desired year $\boldsymbol{X}_{\boldsymbol{y}}$. Therefore, Equation 1 shows how to determine the total number of years that are required to determine the number of users of e-commerce tools by the year $\left(\boldsymbol{X}_{\boldsymbol{y}}\right)$ from the base year $\left(\boldsymbol{X}_{\boldsymbol{I}}\right)$.
The number of e-commerce adopters for each year was considered as a sequence of terms (as seen in equation 2), following which the cumulative total for each successive year was determined till the present year which is 2017 (as seen in equation 3). For example, if an e-commerce tool was adopted from a base year, $\boldsymbol{X}_{\boldsymbol{I}}=2003$; it will be discovered that the total number of terms in the sequence of users from 2003 till 2017 is $\mathrm{t}=2017-2003+1=15$ years. Each partial sum in equation (2) is explicitly defined as shown in equation (3) in terms of the number of adopters $\boldsymbol{X}_{\boldsymbol{y}}$ for each year $n$ for which $1 \leq \mathrm{n} \leq \mathrm{y}$.

$$
\begin{gathered}
\mathrm{t}=2017-2013+1=15 \\
\mathrm{~S}=\mathrm{S}_{1}, \mathrm{~S}_{2}, \mathrm{~S}_{3}, \mathrm{~S}_{4}, \ldots \mathrm{S}_{1}, \ldots, \mathrm{S}_{\mathrm{y}} \\
\text { where } \mathrm{S}_{1}=\mathrm{x}_{1}, \mathrm{~S}_{2}=\left(\mathrm{x}_{1}+\mathrm{x}_{2}\right), \ldots, \mathrm{S}_{15}=\left(\mathrm{x}_{1}+\mathrm{x}_{2}+\ldots \mathrm{x}_{16}\right) \\
\mathrm{S}_{\mathrm{t}}=\mathrm{x}_{1},\left(\mathrm{x}_{1}+\mathrm{x}_{2}\right),\left(\mathrm{x}_{1}+\mathrm{x}_{2}+\mathrm{x}_{3}\right), \ldots\left(\mathrm{x}_{1}+\mathrm{x}_{2}+\ldots \mathrm{x}_{16}\right)
\end{gathered}
$$

Each term shown in (equation 3 ) represents the number of adopters of e-commerce tools at any given year $n$ within an interval of $1 \leq \mathrm{n} \leq \mathrm{y}$. Therefore, the diffusion model for the study is a polynomial equation of degree $m$ which is the best line fit of the cumulative number of adopters of e-commerce by year, years after the base year, $\boldsymbol{X}_{\boldsymbol{I}}$. More so, the e-commerce adoption and diffusion model is a polynomial fit of (equation 2) expressed in terms of (the number of desired years after the base

\begin{tabular}{|c|c|c|c|c|}
\hline \multicolumn{5}{|c|}{ Table 1: Demographic Information of the Respondents } \\
\hline Variables & Groups & & $\begin{array}{c}\text { No. of } \\
\text { Respondents }\end{array}$ & $\%$ \\
\hline \multirow{3}{*}{$\begin{array}{l}\text { Marital } \\
\text { Status }\end{array}$} & Married & & 15 & 11.90 \\
\hline & Single & & 111 & 88.10 \\
\hline & & Total & 126 & $\mathbf{1 0 0 . 0 0}$ \\
\hline \multirow[t]{7}{*}{ Age } & below-21 & & 29 & 23.02 \\
\hline & $21-30$ & & 80 & 63.49 \\
\hline & $31-40$ & & 10 & 7.94 \\
\hline & $41-50$ & & 2 & 1.59 \\
\hline & above-51 & & 4 & 3.17 \\
\hline & Missing & & 1 & 0.79 \\
\hline & & Total & 126 & 100.00 \\
\hline \multirow[t]{4}{*}{ Gender } & Male & & 55 & 43.65 \\
\hline & Female & & 65 & 51.59 \\
\hline & Missing & & 6 & 4.76 \\
\hline & & Total & 126 & 100.00 \\
\hline \multirow{6}{*}{$\begin{array}{c}\text { Education } \\
\text { Level }\end{array}$} & Primary & & 1 & 0.79 \\
\hline & Secondary & & 22 & 17.46 \\
\hline & Polytechnic & & 14 & 11.11 \\
\hline & University & & 88 & 69.84 \\
\hline & Missing & & 1 & 0.79 \\
\hline & & Total & 126 & 100.00 \\
\hline \multirow[t]{5}{*}{ Occupation } & Employed & & 16 & 12.70 \\
\hline & Unemployed & & 17 & 13.49 \\
\hline & Student & & 92 & 73.02 \\
\hline & Missing & & 1 & 0.79 \\
\hline & & Total & 126 & 100.00 \\
\hline
\end{tabular}
year).

\section{RESULTS AND DISCUSSIONS}

\section{A. a. The Demographic Information}

Table 1 above shows that there were more single adopters of e-commerce tools than there were married respondents with a ratio of $8: 1$ for single to married respondents while the 
distribution of the age groups of the respondents revealed that the majority of the respondents were between the ages 21 and 30 years having a proportion of $63 \%$ of respondents followed by those below 20 years with a proportion of $23 \%$. In terms of gender, Table 1 also shows that there were more female adopters of e-commerce than there were male adopters. The results in Table 1 also showed that the majority of adopters of e-commerce were respondents that had university education with a percentage of $70 \%$ followed by adopters who had secondary school education with a proportion of $17 \%$. The information in terms of occupation of respondents shows that the majority of users were students with a proportion of $73 \%$ followed by unemployed respondents with a proportion of $13 \%$ which was equal to the proportion of employed adopters of ecommerce.

\section{b. Analysis on e-Commerce Tools Used and Extent of Use}

\begin{tabular}{|c|c|c|c|}
\hline $\begin{array}{l}\text { E-Commerce } \\
\text { Product }\end{array}$ & Opinion & Response & $\%$ \\
\hline \multirow{5}{*}{$\begin{array}{c}\text { Tablets/Smart } \\
\text { Phones }\end{array}$} & Available and in Use & 119 & 94.44 \\
\hline & Available and not in Use & 4 & 3.17 \\
\hline & Not Available & 3 & 2.38 \\
\hline & Don't Know & 0 & 0.00 \\
\hline & Total & 126 & 100.00 \\
\hline \multirow[t]{5}{*}{ PCs/Laptops } & Available and in Use & 121 & 96.03 \\
\hline & Available and not in Use & 1 & 0.79 \\
\hline & Not Available & 4 & 3.17 \\
\hline & Don't Know & 0 & 0.00 \\
\hline & Total & 126 & 100.00 \\
\hline \multirow[t]{5}{*}{ ATM Cards } & Available and in Use & 122 & 96.83 \\
\hline & Available and not in Use & 0 & 0.00 \\
\hline & Not Available & 4 & 3.17 \\
\hline & Don't Know & 0 & 0.00 \\
\hline & Total & 126 & 100.00 \\
\hline \multirow[t]{5}{*}{ Emails } & Available and in Use & 120 & 95.24 \\
\hline & Available and not in Use & 3 & 2.38 \\
\hline & Not Available & 3 & 2.38 \\
\hline & Don't Know & 0 & 0.00 \\
\hline & Total & 126 & $\mathbf{1 0 0 . 0 0}$ \\
\hline \multirow{5}{*}{$\begin{array}{l}\text { Mobile Money } \\
\text { Transfer }\end{array}$} & Available and in Use & 118 & 93.65 \\
\hline & Available and not in Use & 2 & 1.59 \\
\hline & Not Available & 6 & 4.76 \\
\hline & Don't Know & 0 & 0.00 \\
\hline & Total & 126 & 100.00 \\
\hline \multirow{5}{*}{$\begin{array}{l}\text { E-Commerce } \\
\text { Websites }\end{array}$} & Available and in Use & 116 & 92.06 \\
\hline & Available and not in Use & 7 & 5.56 \\
\hline & Not Available & 3 & 2.38 \\
\hline & Don't Know & 0 & 0.00 \\
\hline & Total & 126 & 100.00 \\
\hline \multirow{5}{*}{ POS Terminals } & Available and in Use & 109 & 86.51 \\
\hline & Available and not in Use & 3 & 2.38 \\
\hline & Not Available & 14 & 11.11 \\
\hline & Don't Know & 0 & 0.00 \\
\hline & Total & 126 & 100.00 \\
\hline
\end{tabular}

Following the distribution of the respondents selected for this study, there was the need of identifying the different ecommerce tools adopted by the respondents as follows: mobile money transfer, tablets/smartphones, e-commerce websites, PCs/laptops, ATM cards, e-mailing services and point-of-sale (POS) terminals. Following the identification of the different ecommerce tools adopted by the respondents selected for this study, there was also the need to understand the availability and usability of the e-commerce tools and the frequency of ecommerce tools usage.

Table 2 shows the responses from 126 respondents selected for this study concerning the availability and usability of e-commerce tools, several observations were made as seen in Table 2 above. $94.4 \%$ of the respondents suggested that tablets/smartphones were available and in use, 3.2\% suggested that they were available but not in use while $2.4 \%$ of the respondents suggested that they were unavailable. $96.0 \%$ of the respondents suggested that $\mathrm{PCs} /$ Laptops were available and in use, $1 \%$ suggested that they were available but not in use while $3.2 \%$ of the respondents suggested that they were unavailable. $96.8 \%$ of the respondents suggested that ATM cards were available and in use while $3.2 \%$ of the respondents suggested that they were unavailable. $95.2 \%$ of the respondents suggested that e-mails were available and in use, $2.3 \%$ suggested that they were available but not in use while $4.8 \%$ suggested that they were unavailable. $93.7 \% \%$ of the respondents suggested that mobile money transfer were available and in use, $1.6 \%$ of the respondents suggested that they were available and not in use while $4.8 \%$ of the respondents suggested that they were unavailable. The result shows that $92.1 \%$ of the respondents were of the opinion that e-commerce websites were available and in use, $5.6 \%$ of the respondents opined that they were available but not in use while $2.4 \%$ of the respondents suggested that they were unavailable. Also, $86.5 \%$ of the respondents agreed that POS terminals were available and in use, $2.4 \%$ of the respondents agreed that they were available and not in use while $11.1 \%$ of the respondents opined that they were unavailable. The results showed that all identified ecommerce tools were available and in use by at least $86 \%$ of the respondents selected for this study while the most generally available and usable e-commerce tools were ATM cards followed by PCs/laptops and e-mails (about 95\% of the respondents).

\section{c. Analysis on Frequency Use of E-commerce Tools}

The frequency of the use of e-commerce tools identified among the respondents selected was elicited from each respondent using four levels of agreement, namely: never, rarely, often, very often while information not provided were tagged as missing. Following the responses from the 126 respondents selected for this study concerning the frequency of use of e-commerce tools, the following were deduced from the results of the responses of the respondents as shown in Table 3. $77 \%$ of the respondents suggested that tablets/smartphones were used at least often $(59.5 \%$ very often) while $11.9 \%$ have never used it. $70.6 \%$ of the respondents suggested that PCs/laptops were used at least often ( $54.8 \%$ very often) while $9.5 \%$ have never used it. $76.2 \%$ of respondents suggested using ATM cards at least 


\begin{tabular}{|c|c|c|c|}
\hline E-Commerce Product & Opinion & Response & $\%$ \\
\hline \multirow{5}{*}{ Tablets/Smart Phones } & Rarely & 14 & 11.11 \\
\hline & Never & 15 & 11.90 \\
\hline & Often & 22 & 17.46 \\
\hline & Very Often & 75 & 59.52 \\
\hline & Total & 126 & 100.00 \\
\hline \multirow{5}{*}{ PCs/Laptops } & Rarely & 25 & 19.84 \\
\hline & Never & 12 & 9.52 \\
\hline & Often & 20 & 15.87 \\
\hline & Very Often & 69 & 54.76 \\
\hline & Total & 126 & 100.00 \\
\hline \multirow[t]{5}{*}{ ATM Cards } & Rarely & 15 & 11.90 \\
\hline & Never & 15 & 11.90 \\
\hline & Often & 25 & 19.84 \\
\hline & Very Often & 71 & 56.35 \\
\hline & Total & 126 & 100.00 \\
\hline \multirow{5}{*}{ Emails } & Rarely & 33 & 26.19 \\
\hline & Never & 14 & 11.11 \\
\hline & Often & 28 & 22.22 \\
\hline & Very Often & 51 & 40.48 \\
\hline & Total & 126 & 100.00 \\
\hline \multirow{5}{*}{ Mobile Money Transfer } & Rarely & 30 & 23.81 \\
\hline & Never & 28 & 22.22 \\
\hline & Often & 38 & 30.16 \\
\hline & Very Often & 30 & 23.81 \\
\hline & Total & 126 & 100.00 \\
\hline \multirow{5}{*}{ E-Commerce Websites } & Rarely & 38 & 30.16 \\
\hline & Never & 44 & 34.92 \\
\hline & Often & 24 & 19.05 \\
\hline & Very Often & 20 & 15.87 \\
\hline & Total & 126 & 100.00 \\
\hline \multirow{5}{*}{ POS Terminals } & Rarely & 41 & 32.54 \\
\hline & Never & 38 & 30.16 \\
\hline & Often & 36 & 28.57 \\
\hline & Very Often & 11 & 8.73 \\
\hline & Total & 126 & 100.00 \\
\hline
\end{tabular}

often (56.4\% very often) while $11.9 \%$ have never used it. $62.7 \%$ of the respondents suggested using e-mails at least often ( $40.5 \%$ very often) while $11.1 \%$ have never used it. $54 \%$ of the respondents suggested using mobile money transfer at least often $(23.8 \%$ very often) while $22.2 \%$ have never used it. $34.9 \%$ of respondents suggested using e-commerce websites at least often $(15.9 \%$ very often) while $34.9 \%$ have never used it before. $37.3 \%$ of respondents suggested using POS terminals at least often ( $8.7 \%$ very often) while $30.2 \%$ have never used it. The results showed that the most commonly used e-commerce tools by the respondents were the tablets/smartphones followed by ATM cards and PCs/laptops with a proportion of at least $70 \%$ using them often while least often used e-commerce tools were e-commerce websites and POS terminals with at most $37 \%$ of respondents.

\section{d. Analysis of Duration of Use of e-Commerce Tools}

From Table 3, in terms of the duration of use of identified e-commerce tools; information relevant to the year of adoption of each e-commerce tool considered for this study was analyzed using tables and charts for presentation. Table 3 below shows the distribution of the number of respondents who started using each e-commerce tool between the years 2003 till 2017 (15 years). The number of users for each e-commerce tool used was recorded for a period of 15 years between the years 2003 and 2017. The choice of 2003 to 2017 was made because this study considered the usage of e-commerce tools in the post GSM era in Nigeria.

From the results, 117 respondents have been using smartphones/tablets since the year 2003 with an initial number of 4 users, 110 respondents have been using PCs/laptops since the year 2003 with an initial number of 5 users, 101 respondents have been using ATM cards since the year 2003 with 1 initial user, 119 users have been using e-mails since the year 2003 with 1 initial user, 119 respondents have been using mobile money transfer since the year 2004 with 1 initial user, 124 respondents have been using e-commerce websites since the year 2004 with 1 initial user while 119 users have been using POS terminals since 2004 with 2 initial users.

Table 3 also reveals that the e-commerce tools used among respondents were, starting from the earliest: Smartphones/Tablets in 2003, POS Terminals in 2004, E-Mails in 2003, PCs/Laptops in 2003, and mobile money transfer in 2004. Also, the most popularly used E-Commerce tools were: E-Commerce websites (98\% of the respondents), E-Mail Services (94\% of the respondents), Mobile Money Transfer (94\% of respondents), POS Terminals (94\% of the respondents), Tablets/Smartphones/PCs/laptops (93\% of respondents), PCs/Laptops (87\% of the respondents) and ATM Cards (80\% of the respondents).

\section{e. Analysis on Formulation of E-Commerce Infusion Model}

Table 4 shows the results for the number of users of each ecommerce tools used by the respondents, the infusion model for e-commerce adoption in Nigeria using the data collected for this study was considered. To formulate the infusion model, the cumulative sum of users/adopters at each consecutive year, $y$ from the base year of adoption (the year the e-commerce tool was first used by users) for all e-commerce tools used till 2017 was considered. Therefore, Table 4 shows the base year considered for each e-commerce tool while Figure 1 shows a graphical plot of the sum of users per consecutive number of years for each e-commerce tool used in Ogun East Senatorial District, Nigeria.

To develop the polynomial function that estimated the trend line for the distribution of each e-commerce tool; the fitting tool function available in the Microsoft ${ }^{\circledR}$ Excel version 2013 Data Analysis Toolkit for automatically estimating trend lines of the distribution of graphical charts was used. Using the base year $\left(\mathrm{X}_{1}\right)$ shown in Table 4 , the total number of users of particular ecommerce by any particular year $\left(\mathrm{X}_{\mathrm{y}}\right)$ tool was estimated from the model by providing the value of time, $x$ which was determined by equation (4).In addition to the identification of the value of $x$ used to estimate the number of users for a particular e-commerce tool for any given year, $X_{y}$ giving a base year $y_{0}$; the infusion model for this study was estimated using the polynomial of degree $m$. Using the Microsoft Excel ${ }^{\circledR}$ Data Analysis tool-pack, the trend line 


\begin{tabular}{|c|c|c|c|c|c|c|c|c|c|c|c|c|c|c|c|c|c|}
\hline E-commerce Tools & '03 & ‘04 & ‘05 & ‘06 & ‘07 & ‘08 & ‘ 09 & '10 & ‘11 & ‘ 12 & '13 & '14 & '15 & '16 & '17 & Total & $\%$ \\
\hline Tablets or Smart Phones & 4 & 2 & 3 & 3 & 8 & 6 & 16 & 17 & 9 & 5 & 12 & 17 & 7 & 4 & 4 & 117 & 93 \\
\hline PCs/ Laptops & 5 & 0 & 2 & 0 & 1 & 2 & 6 & 12 & 19 & 9 & 18 & 13 & 17 & 3 & 3 & 110 & 87 \\
\hline ATM Cards & 1 & 0 & 3 & 2 & 5 & 2 & 1 & 22 & 13 & 12 & 14 & 16 & 2 & 8 & 0 & 101 & 80 \\
\hline E-mail Services & 1 & 1 & 3 & 3 & 4 & 4 & 6 & 20 & 13 & 13 & 5 & 12 & 17 & 11 & 6 & 119 & 94 \\
\hline Mobile Money Transfer & 0 & 1 & 0 & 0 & 0 & 2 & 2 & 11 & 7 & 6 & 8 & 24 & 35 & 18 & 5 & 119 & 94 \\
\hline E-commerce Websites & 0 & 1 & 0 & 0 & 1 & 0 & 1 & 6 & 1 & 5 & 6 & 28 & 51 & 18 & 6 & 124 & 98 \\
\hline POS Terminals & 0 & 2 & 0 & 0 & 0 & 0 & 1 & 0 & 4 & 4 & 10 & 21 & 39 & 27 & 11 & 119 & 94 \\
\hline
\end{tabular}

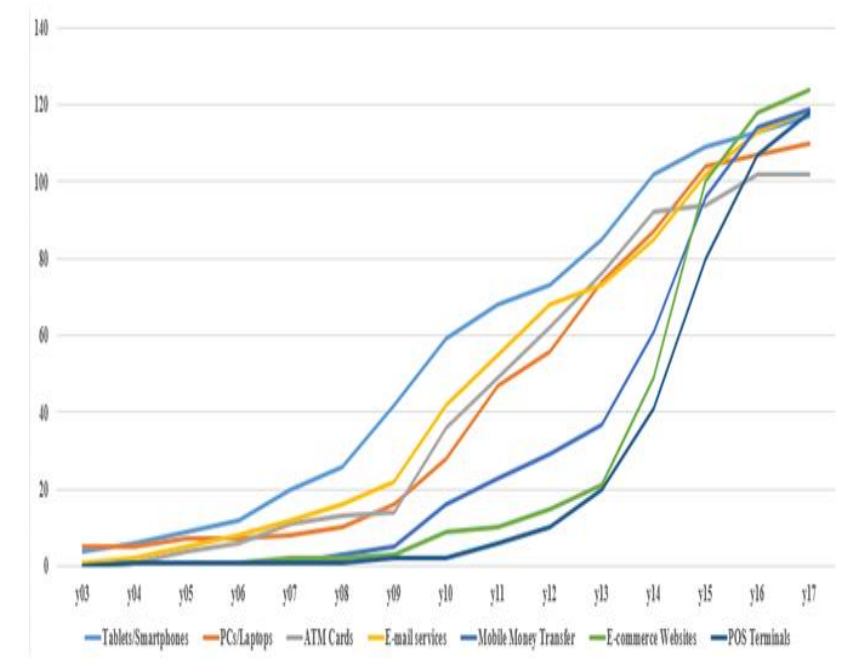

Figure 1: Graphical plot of the cumulative frequency of adopters of e-commerce between 2003 and 2017

estimated from the cumulative distribution of user was used to estimate the infusion model represented as a polynomial estimation of the set of points from a scatter plot of the distribution.

\section{e. Analysis of Infusion Model for the Use of Smartphones/Tablets}

Following the results of the sum of the number of users of smartphones/tablets for each consecutive year, a series of numbers representing the cumulative number of e-commerce adopters for each year was presented. In Table 4, the year of infusion of smartphones/tablets is 2003 with 4 users. Figure 2 below shows the graphical plot of the total number of users of smartphones/tablets for each subsequent year considered from the year of infusion; hence, the period between 2003 till 2017 is 15 years. The points on the horizontal axis indicate the interval of the base year and the year of interest, e.g. the number of users in 2017 is identified by point 15 along the horizontal axis which corresponds to 117 users since 2003. Using the autogenerated trend line functionality of the Excel Data Analysis Tool-pack, the infusion model for smartphones/tablets use taking the base year as 2003 was estimated using a polynomial of degree, $m=5$ stated as follows:
Therefore, to determine the total number of users of smartphones/tablets $x$ years from 2003; equation 4 can be used to estimate the number of users since 2003 that have been using smartphones/tablets in Nigeria.

\section{f. Infusion Model for the Use of PCs/Laptops}

Following the results of the sum of the number of users of PCs/laptops for each consecutive year, a series of numbers representing the cumulative number of e-commerce adopters for each year were presented. In Table 4, the year of infusion of PCs/laptops is 2003 with 5 users. Figure 3 shows the graphical plot of the total number of users of PCs/laptops for each subsequent year considered from the year of infusion; hence, the period between 2003 till 2017 is 14 years. The points on the horizontal axis indicate the interval of the base year and the year of interest, e.g. the number of users in 2017 is identified by point 15 along the horizontal axis which corresponds to 110 users since 2003. Using the auto-generated trend line functionality of the Microsoft Office Excel Data Analysis ToolPack, the infusion model for PCs/laptops use taking the base year as 2003 was estimated using a polynomial of degree, $m=$ 5 stated as follows:

$$
S(x)=-0.005 x^{5}+0.132 x^{4}-1.634 x^{3}+9.175 x^{2}-18.36 x+12.14
$$

Therefore, to determine the total number of users of PCs/laptops $x$ years from 2003; equation 5 can be used to estimate the number of users since 2003 that have been using PCs/Laptops in Nigeria.

\section{g. Infusion Model for the Use of ATM Cards}

Following the results of the sum of the number of users of ATM cards for each consecutive year, a series of numbers representing the cumulative number of e-commerce adopters for each year was presented. In Table 4, the year of infusion of ATM Cards is 2003 with 1 user. Figure 4 shows the graphical plot of the total number of users of ATM Cards for each subsequent year considered from the year of infusion; hence, the period between 2003 till 2017 is 14 years. 


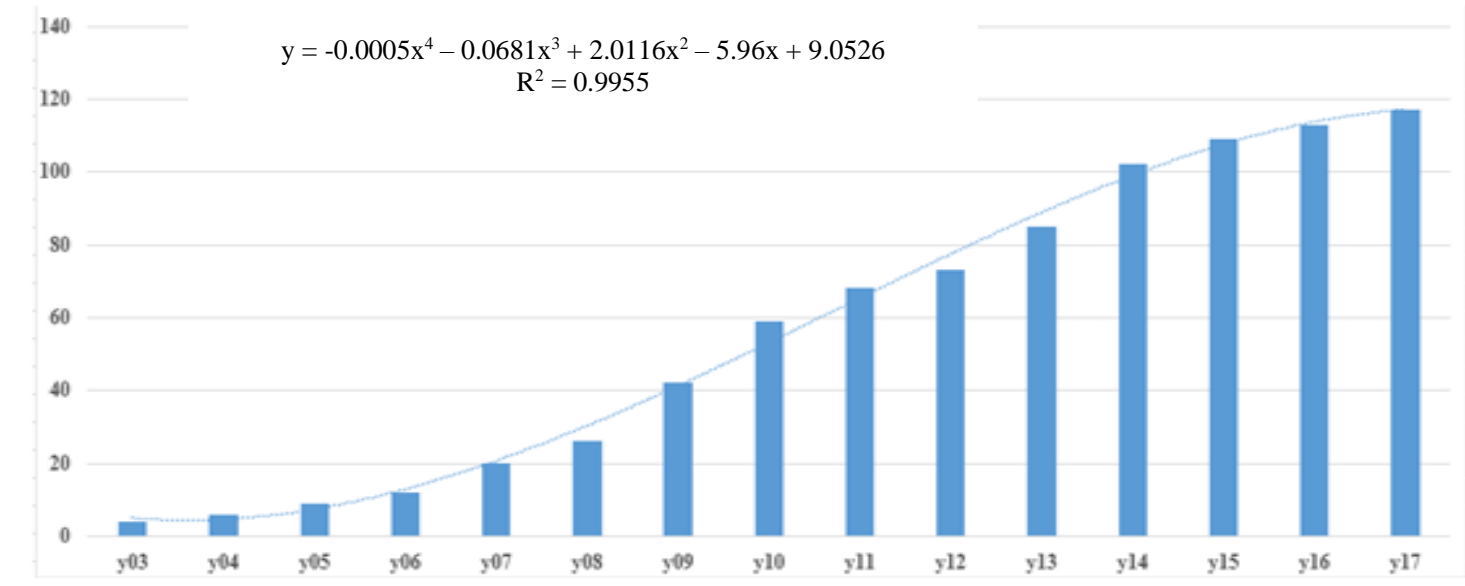

Figure 2: Trend Line of Smartphone/Tablet Adopters

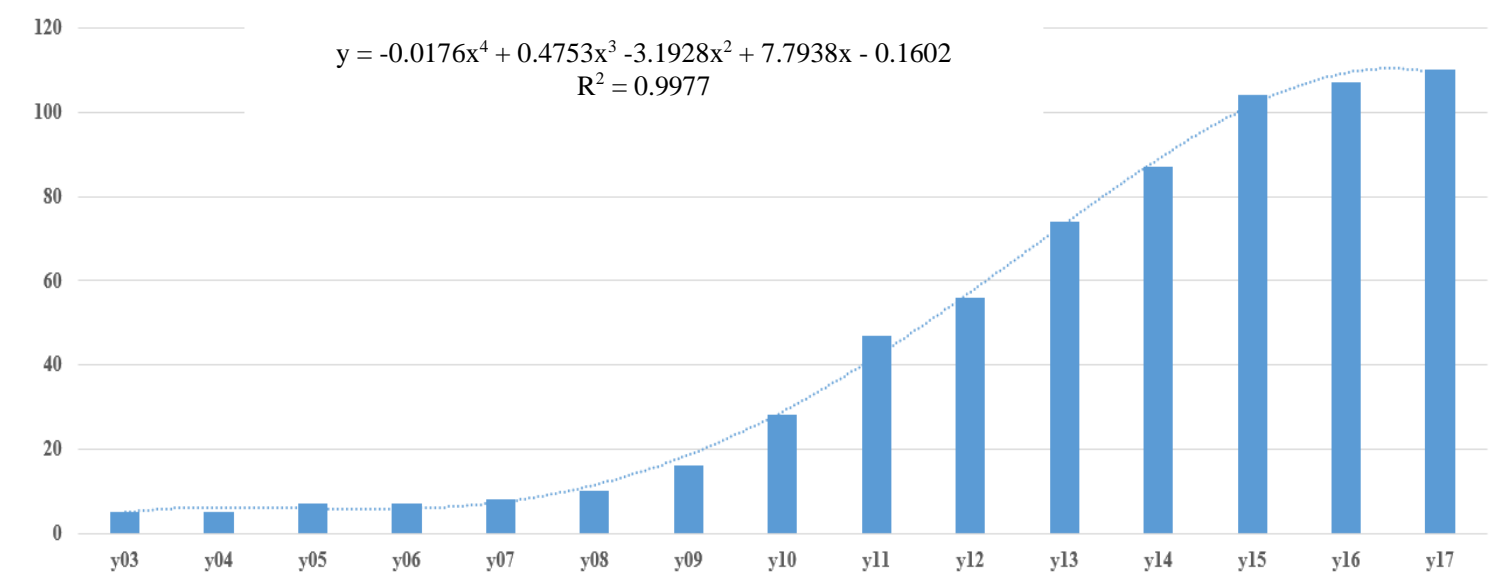

Figure 3: Trend Line of PC/Laptop Adopters

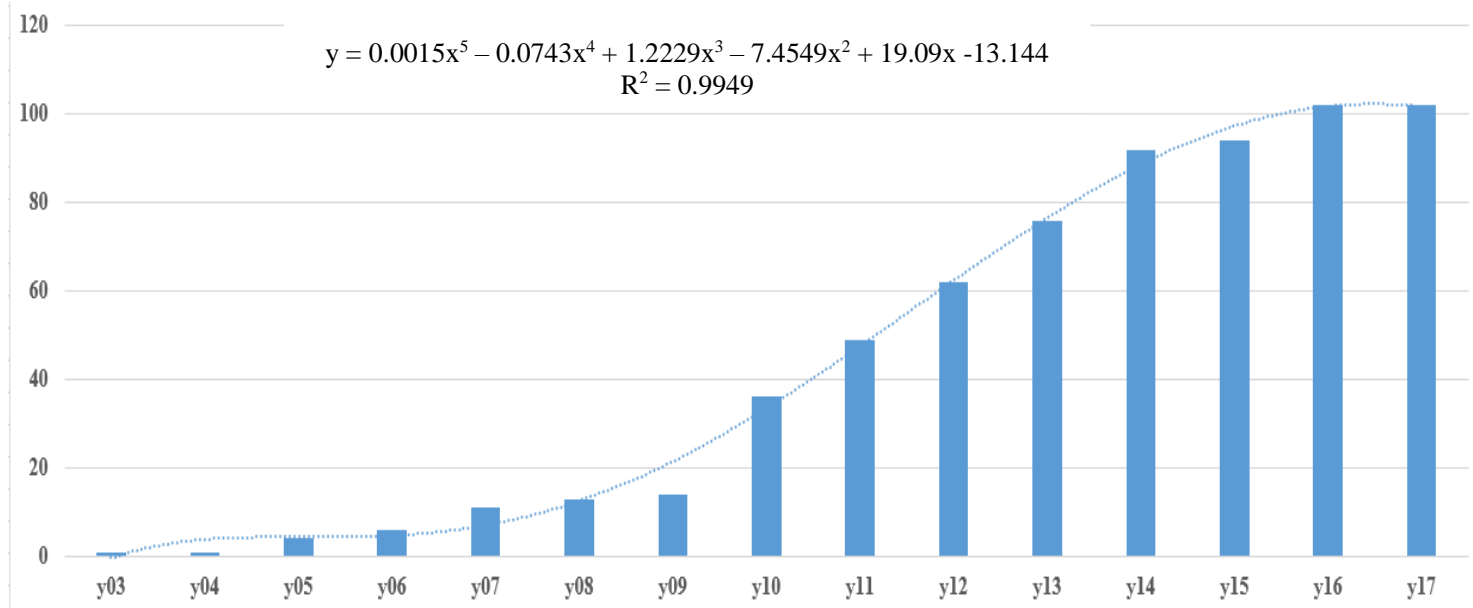

Figure 4: Trend Line of ATM Card Adopters

The points on the horizontal axis indicate the interval of the base year and the year of interest, e.g. the number of users in 2017 is identified by point 15 along the horizontal axis which corresponds to 101 users since 2003. Using the auto-generated trend line functionality of the Excel Data Analysis
Tool-pack, the infusion model for ATM Cards use taking the base year as 2003 was estimated using a polynomial of degree, $m=5$ stated as follows:

$$
S(x)=-0.014 x^{5}+0.272 x^{4}+2.464 x^{3}+10.83 x^{2}-20.37 x+13.14
$$


Therefore, to determine the total number of users of ATM Cards $x$ years from 2003; equation 6 can be used to estimate the number of users since 2003 that have been using ATM Cards in Nigeria.

\section{h. Infusion Model for the Use of E-Mail Services}

Following the results of the sum of the number of users of E-mail services for each consecutive year, a series of numbers representing the cumulative number of e-commerce adopters for each year was presented. In Table 4, the year of infusion of E-mail services is 2003 with 1 user. Figure 5 shows the graphical plot of the total number of users of E-mail services for each subsequent year considered from the year of infusion; hence, the period between 2003 till 2017 is 14 years. The points on the horizontal axis indicate the interval of the base year and the year of interest, e.g. the number of users in 2017 is identified by point 15 along the horizontal axis which corresponds to 119 users since 2003. Using the auto-generated trend line functionality the Excel Data Analysis Tool-pack, the infusion model for E-mail services use taking the base year as 2003 was estimated using a polynomial of degree, $m=5$ stated as follows:

$$
\mathrm{S}(\mathrm{x})=-0.003 \mathrm{x}^{5}+0.072 \mathrm{x}^{4}-0.885 \mathrm{x}^{3}+5.087 \mathrm{x}^{2}-11.66 \mathrm{x}+8.889
$$

Therefore, to determine the total number of users of E-mail services $x$ years from 2003; Equation 7 can be used to estimate the number of users since 2003 that have been using E-mail services in Nigeria. interval of the base year and the year of interest, e.g. the number of users in 2017 is identified by point 15 along the horizontal axis which corresponds to 119 users since 2004. Using the autogenerated trend line functionality of the Excel Data Analysis Tool-pack, the infusion model for Mobile money transfer use taking the base year as 2004 was estimated using a polynomial of degree, $m=5$ stated as follows:

$$
\mathrm{S}(\mathrm{x}) 0.016 \mathrm{x}^{5}-0.313 \mathrm{x}^{4}+2.981 \mathrm{x}^{3}-13896 \mathrm{x}^{2}+2859 \mathrm{x}-17.6
$$

Therefore, to determine the total number of users of mobile money transfer $x$ years from 2000; equation 8 can be used to estimate the number of users since 2004 that have been using mobile money transfer in Nigeria.

\section{j. Infusion Model for E-Commerce Websites}

Following the results of the sum of the number of users of E-commerce websites for each consecutive year, a series of numbers representing the cumulative number of e-commerce adopters for each year was presented. In Table 4 , the year of infusion of E-commerce websites is 2004 with 1 user. Figure 7 shows the graphical plot of the total number of users of Ecommerce websites for each subsequent year considered from the year of infusion; hence, the period between 2004 till 2017 is 14 years. The points on the horizontal axis indicate the interval of the base year and the year of interest, e.g. the number of users in 2017 is identified by point 15 along the horizontal axis which corresponds to 124 users since 2004. Using the auto-generated trend line functionality of the Excel Data Analysis Tool-pack, the infusion model for E-commerce websites use taking the base year as 2004 was estimated using

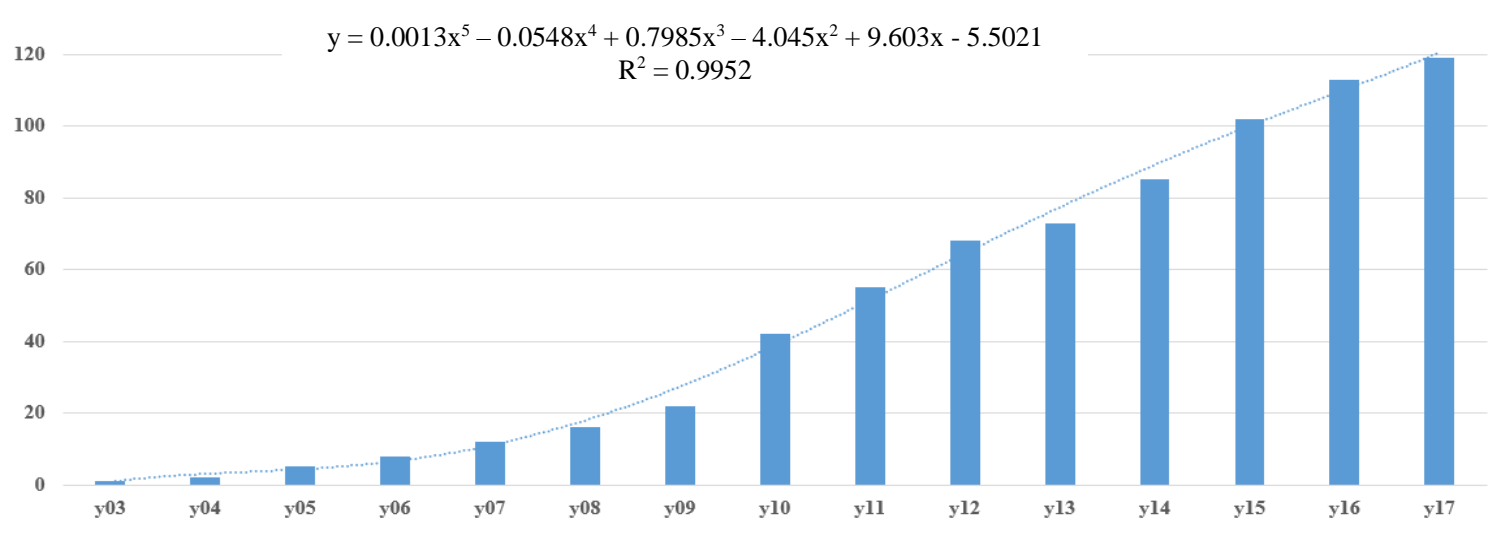

Figure 5: Trend Line of E-mail Service Adopters

\section{$i$. Infusion Model for the Use of Mobile Money Transfer}

Following the results of the sum of the number of users of Mobile money transfer for each consecutive year, a series of numbers representing the cumulative number of e-commerce adopters for each year was presented. In Table 4 , the year of infusion of Mobile money transfer is 2004 with 1 user. Figure 6 shows the graphical plot of the total number of users of Mobile money transfer for each subsequent year considered from the year of infusion; hence, the period between 2004 till 2017 is 13 years. The points on the horizontal axis indicate the

$$
S(x)=0.082 x^{5}-1.209 x^{4}+8.559 x^{3}+29.633 x^{2}+46.16 x-23.23
$$

Therefore, to determine the total number of users of Ecommerce websites $x$ years from 2004; equation 9 can be used to estimate the number of users since 2004 that have been using E-commerce websites in Nigeria. 


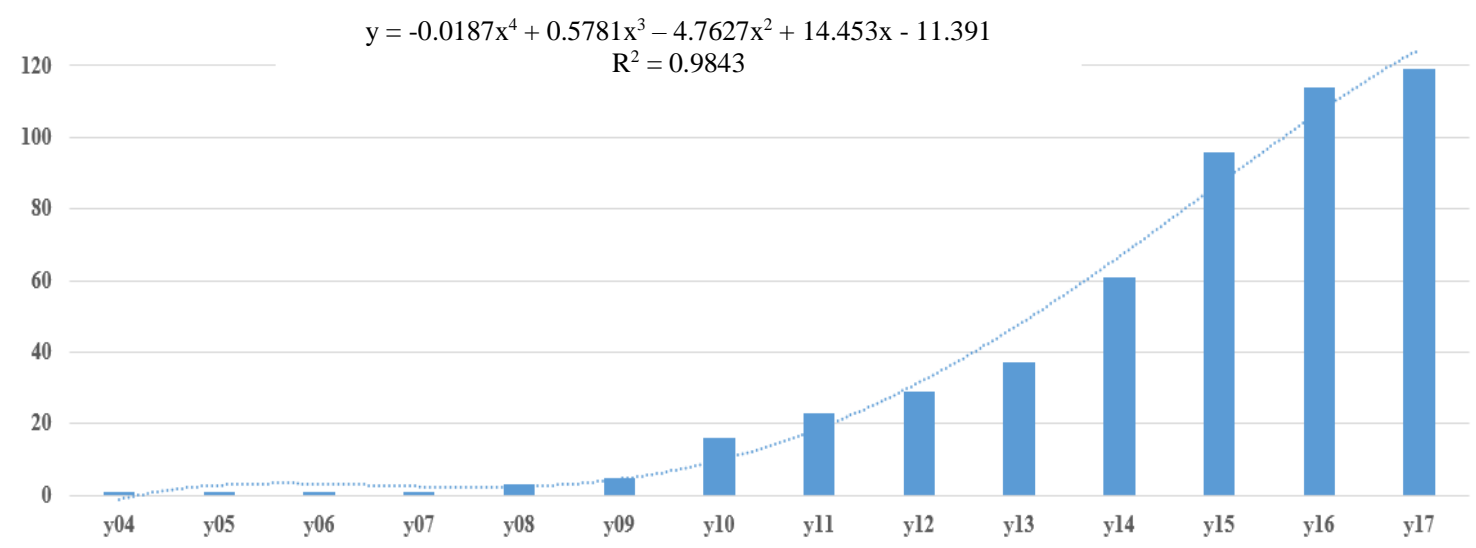

Figure 6: Trend Line of Adopters of Mobile Money Transfer

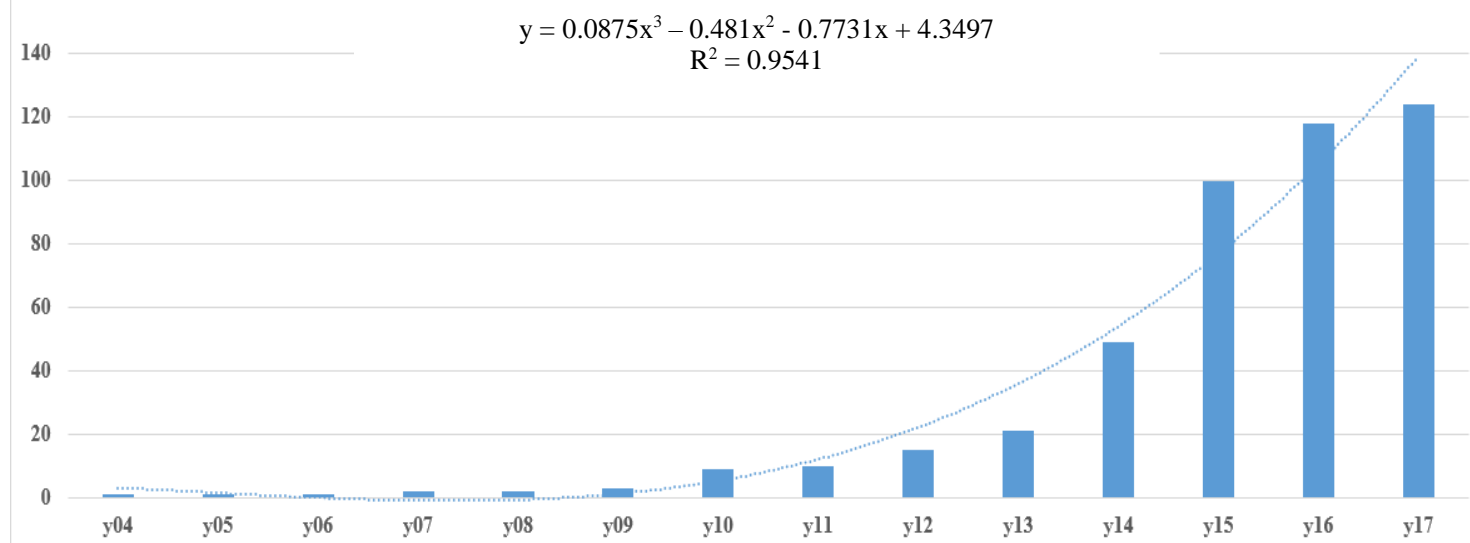

Figure 7: Trend Line of E-commerce Website Adopters

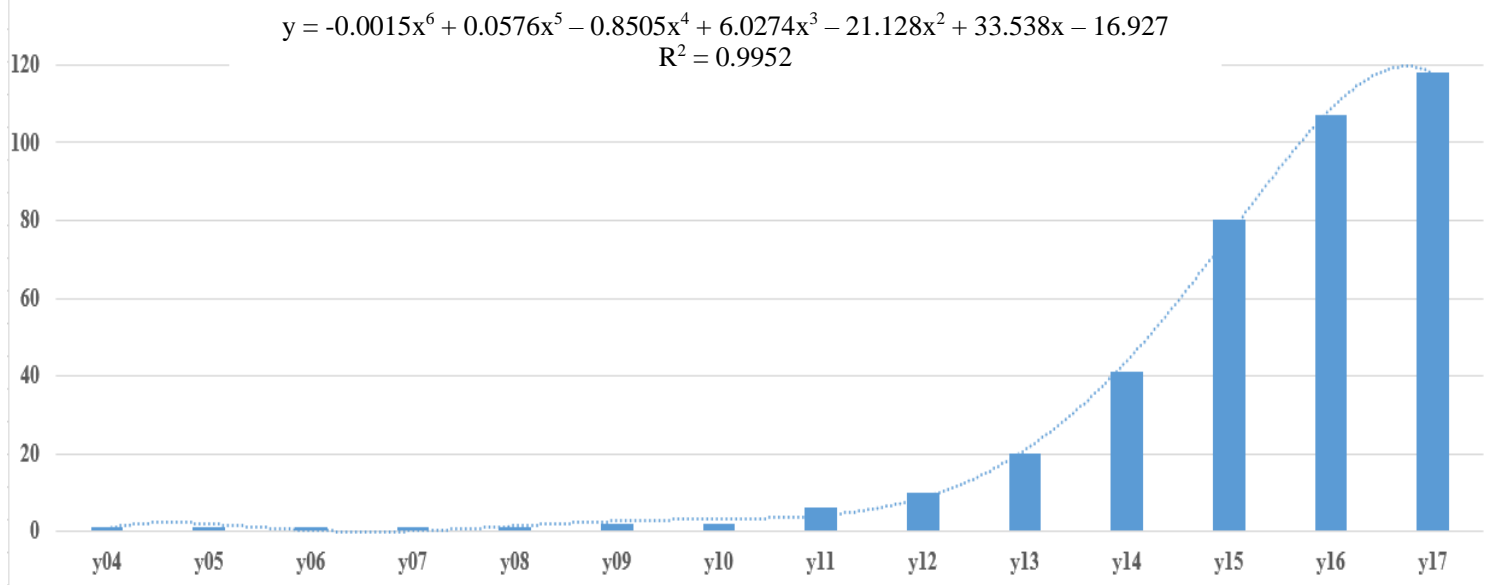

Figure 8: Trend Line for the Adopters of POS Terminal

\section{$k$. Infusion Model for the use of POS Terminals}

Following the results of the sum of the number of users of POS terminals for each consecutive year, a series of numbers representing the cumulative number of e-commerce adopters for each year was presented. In Table 4, the year of infusion of POS terminals is 2004 with 2 users. Figure 8 below shows the graphical plot of the total number of POS terminal users for each subsequent year considered from the year of infusion; hence, the period between 2004 till 2017 is 14 years. 
The points on the horizontal axis indicate the interval of the base year and the year of interest, e.g. the number of users in 2017 is identified by point 15 along the horizontal axis that corresponds to 119 users since 2004. Using the auto-generated trend line functionality of the Excel Data Analysis Tool-pack, the infusion model for POS terminals use taking the base year as 2004 was estimated using a polynomial of degree, $m=5$ stated as follows:

$$
S(x)=0.058 x^{5}-0.851 x^{4}+6.027 x^{3}-21.128 x^{2}+33.54 x-15.93
$$

Therefore, to determine the total number of users of POS terminals $x$ years from 2004; equation 10 can be used to estimate the number of users since 2004 that have been using POS terminals in Nigeria.

\section{DISCUSSIONS}

This paper contributes to an e-commerce research by investigating the infusion and utilization of e-commerce tools in Ogun State, Nigeria. Data was gathered through selfadministered questionnaires and attention was drawn to the need for the evaluation of the use of e-commerce tools by respondents located in the South-Western part of Nigeria particularly in Ogun East Senatorial District as a case study. The study identified e-commerce tools that were used among the selected respondents to include: PCs/Laptops, ATM Cards, E-Mail Services, Mobile Money Transfer, E-Commerce Websites, and POS Terminals. Following the collection of data, descriptive statistics methods using graphs, tables, and charts were used to explain the distribution of the different information collected using the questionnaire consisting of demographic information, use of e-commerce tools, availability, and usability of e-commerce tools.

The results of the study show that they were more female adopters of e-commerce than male adopters owing to the demographic information. The results also showed that the majority of adopters of e-commerce were respondents that had university education with a percentage of $70 \%$ followed by adopters who had secondary school education with a proportion of $17 \%$. The information in terms of occupation of respondents shows that the majority of users of e-commerce were students with a proportion of $73 \%$ followed by unemployed respondents with a proportion of $13 \%$ which was equal to the proportion of employed adopters of e-commerce.

Following the distribution of the respondents selected for this study, the study identified the different e-commerce tools adopted by the respondents to include: Tablets/Smartphones, PCs/Laptops, ATM Cards, E-Mailing Services, Mobile Money Transfer, E-Commerce Websites, and Point-Of-Sale (POS) Terminals. Owing to the availability and usability of ecommerce tools, the results show that all identified e-commerce tools were available and in use by at least $86 \%$ of the respondents selected for this study while the most generally available and usable e-commerce tools were ATM cards followed by PCs/laptops and e-mails (owing to about $95 \%$ responses).
In terms of the duration of use of the identified e-commerce tools, it was discovered that the e-commerce tools used among respondents were, starting from the earliest: Tablets/Smartphones, PCs/laptops, and E-Mail Services all that came into Nigeria in 2003 followed by POS Terminals and Mobile Money Transfer that were adopted in 2004 (post GSM era in Nigeria). Also, the most popularly used e-commerce tools were: E-Commerce websites (98\% of the respondents), E-mail Services (94\% of the respondents), Mobile Money Transfer (94\% of respondents), POS Terminals (94\% of the respondents), tablets/smartphones/PCs/laptops $(93 \%$ of respondents), PCs/Laptops (87\% of the respondents) and ATM Cards ( $80 \%$ of the respondents).

All e-commerce tools were formulated using a degree 5 polynomial equation to achieve the infusion model which required a value derived from the year of interest and the base year (year of adoption) of the e-commerce tool to determine the total number of people who adopted the e-commerce tool by the given year of interest. Hence, the approach of this study has shed light on the technical, organizational, and environmental factors that impede the adoption of e-commerce in Ogun State, Nigeria. This study also brings the work of other researchers into greater focus and extends the existing literature by incorporating theory and model into empirical research design. As a result, this study would enable the development of a business model for firms still contemplating online retail strategy in the decision-making process for the planning and implementation of effective e-commerce, in Ogun East Senatorial District, and other parts of Nigeria as a whole.

\section{CONCLUSION}

This paper has contributed to the body of knowledge by suggesting an innovative approach to model the growth of ecommerce in Ogun East Senatorial District. The internal and external barriers that hinder the growth of e-commerce in the Senatorial District were equally well mentioned in the related works. Based on the findings of the study, the e-commerce tools identified to be used among the 126 respondents selected for the study were: Tablets/Smartphones, PCs/Laptops, ATM Cards, E-Mailing Services, Mobile Money Transfer, E-Commerce Websites, and Point-Of-Sale (POS) Terminals. Following the analysis of data collected from 126 questionnaires distributed to the respondents selected for the study, several observations were made; the majority of the e-commerce adopters were single female students aged between 21 and 30 years of age with university education owing to a proportion of $63 \%$ of the respondents.

The results showed that all the identified e-commerce tools were available and in use by at least $86 \%$ of the respondents while the most generally available and usable e-commerce tools were Tablets/Smartphones, ATM cards followed by PCs/laptops and e-mails owing to a proportion of $95 \%$. The results further showed that the e-commerce tools earlier adopted were the Tablets/Smartphones (in 2003) followed by PCs/Laptops (in 2003), ATM Cards (in 2003), E-Mail Services 
(in 2003), Mobile Money Transfer (in 2004), E-Commerce Websites (in 2004) and POS Terminals (in 2004).

It was also deduced from the results that the most popular ecommerce tools were: e-commerce websites (98\% responses), E-Mail Services (94\% responses), Mobile Money Transfer (94\% responses), POS Terminals (94\% responses), Tablets/Smartphones (93\% responses), PCs/Laptops (87\% responses), and ATM Cards (80\% responses). Therefore, the study would be useful for modeling most other technological innovations in the future. More so, further research can be done in the area of investigating the magnitude of adoption of ecommerce in developing countries.

\section{RECOMMENDATIONS}

For sustainable e-commerce adoption and diffusion, the three (3) tears of government, both the local, state and federal must emphasize enabling e-commerce technology to grow, by creating relevant capacity building programmes for $\mathrm{e}$ commerce users, improving the IT infrastructures and real government incentives while at the same time taking cognizance of the effect of environmental factors. Governments at all levels should promote the use and development of ecommerce technology, notably by reducing the cost of access to technology, through the liberation of trade in software and hardware. The adoption of e-commerce in Ogun East Senatorial District is only at its earliest stage, therefore, Ogun State government should play an active role by creating an enabling environment that would educate and encourage more users to adopt the technology in the state because by so doing, it would boost the economy of the state and create more jobs for the citizens of the state. The methodological approach used in this paper can be applied in formulating infusion models for ecommerce adoption across Nigeria as a whole through national efforts towards gathering information about users of different classes of e-commerce tools from users to understand the process of adoption on a national scale.

\section{REFERENCES}

[1] T. M. Nisar and G. Prabhakar, What factors determine e-satisfaction and consumer spending in e-commerce retailing? Journal of Retailing and Consumer Services, 39, pp. 135-144, 2017.

[2] M. Kutz, Introduction to e-commerce: Combining business and information technology ( $1^{\text {st }}$ Ed.), 2016, ISBN: 978-87-403-1520-2. [Online]. Available: https://irpcdn.multiscreensite.com/1c74f035/files/uploaded/introduction-to-ecommerce.pdf

[3] E. M. Bukohwo and L. A. Bishams, Assessing the adoption of electronic commerce by customers in Bauchi metropolis. American International Journal of Contemporary Scientific Research, 1(2), pp. 67-74, 2014.

[4] P. O. B. Ochola, E-commerce adoption among micro, small, and medium sector in Nairobi County, Kenya. Master's Thesis submitted to the Department of Computer Science, Kenyatta University Nairobi, Kenya, 2013.

[5] A. P. Shemi, Factors affecting e-commerce adoption in small and medium enterprises: An interpretive study of Botswana. Masters Thesis submitted to the Department of Business Administration, University of Salford, UK, 2012.
[6] O. I. Moisescu, From perceptual corporate sustainability to customer loyalty: A multi-sectorial investigation in a developing country, Economic Research Ekonomska Istraživanja, 31(1), pp. 55-77, 2018.

[7] S. Mukhopadhyay, S. Samaddar and S. Nargundkar, Predicting electronic commerce growth: An integration of diffusion and neural network models. Journal of Electronic Commerce Research, 9(4), pp. 280-295, 2008.

[8] S. Al-Hudhaif, and A. Alkubeyyer, E-commerce adoption factors in Saudi Arabia. International Journal of Business and Management, 6(9), pp. 122-133, 2011.

[9] T. Haryanti and A. P. Subriadi, Factors and theories e-commerce adoption: A literature review. International Journal of Electronic Commerce Studies, 11(2), pp. 87-106, 2020, doi: 10.7903/ijecs.1910.

[10] L. Xiao, F. Guo, F. Yu, and S. Liu, The effects of online shopping context cues on consumers' purchase intention for cross-border ECommerce sustainability, Sustainability, 11, 2019, doi:10.3390/su11102777. [Online]. Available: https://www. file://C:/Users/FAMILY\%20SYSTEM/Downloads/sustainability11-02777.pdf

[11] J. Oláh, N. Kitukutha, H. Haddad, M. Pakurár, D. Máté, and J. Popp, Achieving sustainable e-commerce in environmental, social and economic dimensions by taking possible trade-offs, Sustainability (Switzerland), 2018. [Online]. Available: https://www.mdpi.com/2071-1050/11/1/89

[12] R. Ashrafi and M. Murtaza, Use and impact of ICT on SMEs in Oman. Electronic Journal of Information Systems Evaluation, 11(3), pp. 125-138, 2008.

[13] P. Golding, O. Donaldson, V. Tennant, and K. Black, An analysis of factors affecting the adoption of ICT by MSMEs in Rural and Urban Jamaica, 2008.

[14] F. Olusegun, A. Gabriel, S. Sushil, and J. Zhang, Factors affecting the adoption of e-commerce: A study in Nigeria. Journal of Applied Sciences, 6(10), pp. 2224-2230, 2006.

[15] L. Arendt, Barriers to ICT adoption in SMEs: How to bridge the digital divide. Journal of Systems Information Technology, 10(2), pp. 93-108, 2008.

[16] I. Apulu and A. Latham, Information and communication technology adoption: Challenges for Nigerian SMEs. TCM Academic Journal, 4(2), pp. 64-80, 2009.

[17] J. Abor, and P. Quartey, Issues in SME development in Ghana and South Africa. International Research Journal for Financial Economics, 39, pp. 218-228, 2010.

[18] I. A. Irefin, I. A. Abdul-azeez and A. A. Tijani, An investigative study of the factors affecting the adoption of information \& communication technology in small \& medium scale enterprises in Nigeria. Australian Journal of Business and Management Research, 2(2), 1-9, 2012.

[19] C. A. Aydemir, Survey aimed at e-commerce applications in firms operating in Diyarbakir organized industrial zone. International Journal of Business and Social Science, 4(1): 43-59, (2013)

[20] B. Yoo and M. Jang, A bibliographic survey of business models, service relationships, and technology in electronic commerce, Journal of Electron. Commerce Research Application, 33, 2019.

[21] V. Zwass, The framework and the big ideas of e-business in: Martínez-López, pp. 3-14, 2014.

[22] Tornatzky, L. G. \& Fleischer, M. (1990). The Processes of Technological Innovation, Issues in Management Series. Lexington Books, New York, NY.

[23] E. Rogers, Diffusion of innovations (5th Ed.). New York, NY: Simon \& Schuster, 2003. 